\title{
PENGETAHUAN, SIKAP, DAN PERILAKU IBU DALAM PEMENUHAN GIZI BALITA: SEBUAH SURVAI
}

\author{
Sanny Rachmawati Setyaningsih ${ }^{1 *}$, Nur Agustini ${ }^{2}$ \\ 1. Fakultas Ilmu Keperawatan, Universitas Indonesia, Depok 16424, Indonesia \\ 2. Departemen Keperawatan Anak, Fakultas Ilmu Keperawatan, Universitas Indonesia, Depok 16424, Indonesia \\ *E-mail: sanny_rachmawati_a5@yahoo.com
}

\begin{abstract}
Abstrak
Gizi merupakan faktor yang berperan penting dalam pertumbuhan dan perkembangan balita. Pada aspek gizi, peran orang tua terutama ibu sangatlah penting karena merupakan orang yang terdekat bagi anak. Penelitian pendahuluan ini bertujuan memperoleh gambaran tentang pengetahuan, sikap, dan perilaku ibu dalam pemenuhan gizi balita. Survai ini melibatkan ibu yang memiliki anak berusia 13 sampai 59 bulan di Wilayah Pancoran Mas, Depok, Jawa Barat sebanyak 112 responden. Teknik pengambilan sampel yang digunakan adalah multistage random sampling dan consecutive sampling. Hasil survai menunjukkan sebanyak 75,9\% ibu berpengetahuan cukup, 57,1\% ibu memiliki sikap yang cukup baik, serta $71,4 \%$ ibu berperilaku baik dalam pemenuhan gizi balita. Hasil penelitian ini menunjukkan kondisi yang positif tetapi perlu diteliti lebih mendalam lagi sehingga permasalahan utama berkaitan dengan gizi balita dapat diidentifikasi.
\end{abstract}

Kata kunci: balita, pemenuhan gizi, pengetahuan ibu, perilaku ibu, sikap ibu

\begin{abstract}
Knowledge, Attitude, and Behavior of Mothers Related to Nutritional Meeting for Underfive Years Children: A Survey. Nutrition is an important factor for the growth and development of children aged under five years. On nutritional aspects, the role of parents, particularly mothers have a main role because they were the closest person to the children. This survey was to identify mother's nutrition knowledge, attitude, and behavior with involving 112 mothers who had children aged between 13 until 59 months. Respondents were selected by multistage random sampling and consecutive sampling technique. The results showed that $75.9 \%$ of mothers have moderate knowledge, $57.1 \%$ of mothers have moderate attitude, and $71.4 \%$ of mothers show good behavior toward nutrition compliance. The results of this research can be used as an idea to develop strategies to address nutritional problems in children aged under five years.
\end{abstract}

Keywords: children aged under five years, mother's attitude, mother's behavior, mother's knowledge, nutrition compliance

\section{Pendahuluan}

Pada masa balita, anak mengalami proses pertumbuhan dan perkembangan yang pesat baik secara fisik, mental, maupun sosial. Anak memerlukan gizi dari makanan sehari-hari dalam jumlah yang tepat dan kualitas yang baik. Gizi yang baik ini sangat penting untuk kelangsungan hidup anak, proses tumbuh kembang, pemeliharaan dan pemulihan kesehatan, serta imunitas (Lozoff, Jimenez, \& Smith, 2006; Victora et al., 2008). Gizi yang adekuat juga merupakan hal yang penting untuk mencapai indikator keempat Millenium Development Goals (MDGs).

Di Indonesia, saat ini terjadi fenomena masalah gizi ganda. Pergeseran dalam masalah gizi dan kesehatan ini terjadi seiring dengan perubahan gaya hidup dan kondisi lingkungan di masyarakat. Hasil Riskesdas 2010 menunjukkan prevalensi gizi kurang menurun menjadi $17, \%$, namun gizi lebih mengalami peningkatkan menjadi $5,8 \%$. Berdasarkan indeks massa tubuh, pada tahun 2010, jumlah balita kurus menurun sedikit 
menjadi $13,3 \%$ dan balita gemuk meningkat menjadi 14\% (Kementerian Kesehatan RI, 2010).

Berdasarkan laporan Profil Kesehatan Kota Depok (2012), pada tahun 2011 diketahui dari hasil penimbangan pada 115.140 balita terdapat 5.195 balita $(4,51 \%)$ gizi lebih, 104.876 balita gizi baik (91,09\%), 4.940 balita gizi kurang $(4,29 \%)$ dan 129 balita gizi buruk $(0,11 \%)$ dan tahun 2012 dilaporkan bahwa dari 121.702 balita hasil penimbangan balita terdapat 4.746 (4\%) balita dengan gizi lebih, 111.112 (91\%) balita gizi baik dan $5.563(5 \%)$ balita gizi kurang dan 120 balita $(0,1 \%)$ balita Gizi buruk. Dilaporkan juga, pada tahun 2012, sebanyak 27 balita gizi buruk dari Kecamatan Pancoran Mas mendapatkan perawatan di RS. Khususnya di wilayah kerja puskesmas Pancoran Mas, berdasarkan penelitian Putri (2008) diketahui sebesar $14.4 \%$ anak mengalami kekurusan dan $20.1 \%$ anak mengalami kegemukan.

Pada pemenuhan gizi seorang balita, ibu memegang peranan yang sangat penting. Ibu merupakan orang yang paling dekat dengan anak, orang pertama yang berhubungan dengan anak, dan yang memberikan alokasi waktu lebih banyak dalam pengasuhan anak (Byrd-Bredbenner, Abbot, \& Cussler, 2008; Wong, Hockenberry-Eaton, Wilson, Winkelstein, \& Schwartz, 2001).

Menurut Green (1980 dalam Notoatmodjo, 2007), pengetahuan dan sikap yang dimiliki seseorang merupakan faktor predisposisi yang memengaruhi perilaku. Jika ibu memiliki pengetahuan yang baik tentang gizi balita, diharapkan ibu juga akan memiliki sikap dan perilaku yang baik pula dalam pemenuhan gizi balita. Pengetahuan ibu mengenai gizi akan berpengaruh terhadap hidangan dan mutu makanan yang disajikan untuk anggota keluarga termasuk balita. Sikap ibu dalam memenuhi kebutuhan gizi balita juga sangat penting. Sikap merupakan faktor yang memengaruhi perilaku kesehatan seseorang. Perubahan sikap secara berkelanjutan dapat memengaruhi perilaku seseorang, dimana perilaku pemenuhan gizi yang baik dapat meningkatkan status gizi anak (Apooh, Yaa, \& Krekling, 2005). Oleh karena itu, perlu dilakukan survai untuk mendapatkan gambaran pengetahuan, sikap, dan perilaku ibu dalam pemenuhan gizi balita di wilayah Puskesmas Pancoran Mas.

\section{Metode}

Survai ini menggunakan pengambilan sampel dengan multistage random sampling dan consecutive sampling, untuk mendapatkan data dari 112 ibu di Posyandu. Kriteria inklusi mencakup ibu yang memiliki balita berusia 13 sampai 59 bulan, berdomisili di wilayah Kecamatan Pancoran Mas, dan dapat membaca dan menulis. Kriteria eksklusi yakni ibu yang memiliki balita dengan penyakit kronik yang menyebabkan gangguan gizi, serta balita dengan gangguan pertumbuhan dan perkembangan. Apabila ibu memiliki lebih dari satu balita, maka balita yang terkecil yang dijadikan sampel.

Pertanyaan dalam kuesioner pengetahuan ibu dinilai dengan menggunakan skala Guttman meliputi 25 pertanyaan. Total skor dikategorikan menjadi 1: kurang, jika jawaban benar $<60 \%$, 2: cukup, jika jawaban benar $60-80 \%$, dan 3 : baik, bila jawaban benar $>80 \%$. Pertanyaan dalam kuesioner sikap dan perilaku ibu dinilai dengan menggunakan skala Likert dengan masingmasing sebanyak 15 pertanyaan. Total skor selanjutnya dikategorikan dengan menganalogikan standar penilaian variabel pengetahuan. Data tentang balita diperoleh dari buku KIA, pada kunjungan terakhir.

Penelitian ini telah melalui proses etik dan administrasi yang semestinya. Semua responden yang terlibat dalam penelitian ini telah mendapatkan informed consent.

\section{Hasil}

Sebagian besar responden berusia antara 21-40 tahun $(97,3 \%)$, dengan dua anak (42\%), berlatarbelakang pendidikan sekolah menengah $(77,7 \%)$, ibu rumah tangga $(86,6 \%)$, penghasilan keluarga di atas dua juta $(52,7 \%)$, dan bersuku Betawi $(37,5 \%)$. Secara rinci data dapat dilihat pada Tabel 1. 
Data tentang balita dapat dilihat dari Tabel 2. Mayoritas balita berusia 13 hingga 26 bulan $(64,3 \%)$, laki-laki $(57,1 \%)$, sehat $(55,4 \%)$, status gizi normal $(88,4 \%)$.

Tabel 1. Karakteristik Responden

\begin{tabular}{lrr}
\hline \multicolumn{1}{c}{ Variabel } & Frekuensi (n) & Persentase (\%) \\
\hline Usia ibu & & \\
$\leq 20$ & 109 & 0 \\
$21-40$ & 3 & 27.3 \\
$41-65$ & & \\
Jumlah anak & 41 & 36.6 \\
1 & 47 & 42 \\
2 & 24 & 21.4 \\
$\geq 3$ & & \\
Pendidikan & 4 & 3.6 \\
$\leq$ SD (dasar) & 87 & 77.7 \\
SMP-SMA (menengah) & 21 & 18.7 \\
Akademi-PT (tinggi) & & \\
Pekerjaan & & 86.6 \\
Tidak bekerja & 97 & 13.4 \\
Bekerja & 15 & \\
Penghasilan & & 47.3 \\
< Rp 2.042.000 & 53 & 52.7 \\
$\geq$ Rp 2.042.000 & 59 & \\
Suku & & 36.6 \\
Jawa & 41 & 3.6 \\
Padang & 4 & 21.4 \\
Betawi & 42 & \\
Sunda & 24 & \\
Lain-lain & 1 & \\
& & \\
\end{tabular}

Tabel 2. Karakteristik Balita

\begin{tabular}{lcc}
\hline \multicolumn{1}{c}{ Variabel } & Frekuensi (n) & Persentase (\%) \\
\hline Usia anak & & \\
13-36 bulan & 72 & 64.3 \\
37-59 bulan & 40 & 35.7 \\
Jenis kelamin & & \\
Laki-laki & 64 & 57.1 \\
Perempuan & 48 & 42.9 \\
Status kesehatan & & \\
Sehat & 62 & 55.4 \\
Pernah/sedang sakit & 50 & 44.6 \\
- Batuk & 31 & 62 \\
- Panas & 21 & 42 \\
- Diare & 1 & 2 \\
- Pilek & 24 & 48 \\
- Lain-lain & 2 & 4 \\
Status gizi & & \\
Sangat kurus & 0 & 0 \\
Kurus & 0 & 0 \\
Normal & 99 & 88.4 \\
Gemuk & 13 & 11.6 \\
\hline
\end{tabular}

Tabel 3. Pengetahuan, Sikap, dan Perilaku Ibu dalam Pemenuhan Gizi Balita

\begin{tabular}{lcc}
\hline \multicolumn{1}{c}{ Variabel } & Frekuensi (n) & Persentase (\%) \\
\hline Pengetahuan & & \\
Kurang & 5 & 4.5 \\
Cukup & 85 & 75.9 \\
Baik & 22 & 19.6 \\
Sikap & & \\
Kurang baik & 1 & 0.9 \\
Cukup baik & 60 & 57.1 \\
Baik & 51 & 42 \\
Perilaku & & \\
Kurang baik & 0 & 0 \\
Cukup baik & 32 & 28.6 \\
Baik & 80 & 71.4 \\
\hline
\end{tabular}

Responden sebagian besar berpengetahuan, dan bersikap cukup, $(75,9 \%, 57,1 \%)$ dan berperilaku baik $(71,4 \%)$ dalam pemenuhan gizi balita.

\section{Pembahasan}

Mayoritas ibu berada pada rentang usia 21-40 tahun atau fase dewasa awal. Pada fase ini, tanggung jawab dalam mengasuh balita termasuk pola asuh dalam hal gizi merupakan tahapan kehidupan yang wajar dialami (Potter \& Perry, 2005). Selain itu, sebagian besar ibu mempunyai dua orang anak. Hasil penelitian ini juga relevan dengan usia yang berada pada rentang produktif. Mayoritas responden memiliki tingkat pendidikan menengah yakni dari SMP hingga SMA. Hasil penelitian ini sejalan dengan penelitian Putri (2008) dan data demografi Kota Depok secara umum.

Pengambilan data pada penelitian ini sebagian besar dilakukan pada hari kerja mulai pukul 08.00-12.00 WIB di Posyandu kelurahan Pancoran Mas sehingga data menunjukkan mayoritas ibu adalah ibu rumah tangga. Selain itu, sebagian besar responden memiliki pendapatan keluarga lebih dari UMK Depok. Hasil penelitian ini sejalan dengan penelitian Huriah (2006). Kota Depok merupakan kota yang berbatasan langsung dengan wilayah DKI Jakarta, yang banyak penduduk yang merupakan pendatang. Hal ini pun memengaruhi hasil penelitian dimana mayoritas ibu bersuku Betawi. 
Mayoritas balita pada penelitian ini berada pada masa toddler (13-36 bulan). Menurut perkembangan psikososial Erikson, pada masa ini anak berada dalam periode otonomi versus ragu-ragu/ malu. Menurut Uripi (2004) pada usia 1-3 tahun, anak menerima makanan dari apa yang disediakan ibunya. Oleh sebab itu, toddler disebut juga dengan konsumen pasif. Hasil penelitian juga menjelaskan bahwa mayoritas balita berjenis kelamin laki-laki. Hasil ini pun sesuai dengan data Bulan Penimbangan Balita (BPB) tahun 2012, dimana balita berjenis kelamin laki-laki lebih banyak daripada perempuan.

Status kesehatan anak dalam satu bulan terakhir adalah sehat. Hasil penelitian ini berbeda dengan penelitian Hidayati (2011) tentang tugas kesehatan keluarga, karakteristik keluarga dan anak dengan status gizi balita di Wilayah Puskesmas Pancoran Mas Kota Depok yang mengatakan mayoritas anak mengalami sakit. Berdasarkan indeks antropometri $\mathrm{BB} / \mathrm{TB}$ diketahui bahwa mayoritas balita berstatus gizi normal. Selain itu, dalam penelitian ini juga tidak ditemukan balita dengan status gizi sangat kurus maupun kurus, akan tetapi ditemukan balita dengan status gizi gemuk. Hasil penelitian ini lebih rendah bila dibandingkan dengan penelitian yang dilakukan Putri (2008). Faktor yang memengaruhi perbedaan hasil penelitian ini yakni dalam sebulan terakhir mayoritas anak berstatus sehat, telah terbentuk 7 pos gizi di kelurahan Pancoran Mas, peran kader yang cukup aktif, adanya RW siaga, serta kegiatan posyandu yang cukup aktif.

Hasil penelitian menunjukkan bahwa mayoritas ibu berpengetahuan cukup mengenai pemenuhan gizi balita. Hal ini berbeda dengan penelitian Ihsan, Hiswani, dan Jemadi (2013) di Desa Teluk Rumbia Aceh, yang menemukan mayoritas ibu berpengetahuan kurang.

Perbedaan hasil penelitian ini dapat dikarenakan perbedaan dalam hal pengkategorian variabel pengetahuan. Pada penelitian Ihsan et al. (2013) variabel pengetahuan dibedakan menjadi baik dan kurang baik, sedangkan pada penelitian ini dibedakan menjadi baik, cukup, dan kurang.
Selain itu, perbedaan karakteristik responden atau wilayah turut memengaruhi hasil penelitian.

Pada penelitian ini, mayoritas responden berpendidikan menengah. Pendidikan merupakan faktor yang memengaruhi pengetahuan gizi seseorang. Semakin tinggi tingkat pendidikan seseorang, maka semakin tinggi pula kemampuan orang tersebut dalam menangkap informasi yang dapat meningkatkan pengetahuannya (Khomsan, 2000).

Berdasarkan peninjauan per subvariabel, diketahui bahwa responden memiliki pengetahuan baik tertinggi pada subvariabel memilih makanan, sedangkan memiliki pengetahuan kurang tertinggi pada subvariabel masalah makanan dan gizi anak. Peneliti berasumsi pengetahuan ibu yang baik dalam hal memilih makanan salah satunya karena perkembangan media massa baik elektronik dan cetak. Hal tersebut mempermudah ibu mendapatkan informasi mengenai cara memilih sayuran, buah, daging, ataupun ikan yang baik untuk anak.

Pada subvariabel masalah makan dan gizi anak, masih banyaknya ibu yang memiliki pengetahuan kurang baik dikarenakan terbatasnya pengetahuan ibu mengenai istilah masalah gizi pada anak contohnya seperti istilah KEP (kurang energi protein).

Berdasarkan hasil analisis terlihat bahwa responden dengan pengetahuan yang baik, status gizi balitanya juga baik. Hasil penelitian ini didukung oleh penelitian Khotimah, Siregar, dan Mardiana (2012) yang mengungkapkan ibu yang memiliki pengetahuan baik, memiliki anak dengan status gizi yang baik pula.

Hasil penelitian mengenai sikap ibu dalam pemenuhan gizi balita didapatkan data bahwa mayoritas ibu memiliki sikap yang cukup baik. Hasil penelitian ini berbeda dengan hasil penelitian Vereecken dan Maes (2010) di Belgia yang menyatakan mayoritas ibu memiliki sikap yang baik dalam pemenuhan gizi anak.

Perbedaan hasil penelitian ini dengan penelitian Vereecken dan Maes (2010) dapat dipengaruhi 
oleh karakteristik responden penelitian. Pada penelitian Veerecken dan Maes, mayoritas ibu memiliki tingkat pendidikan tinggi, sedangkan pada penelitian ini mayoritas ibu memiliki tingkat pendidikan menengah. Salah satu komponen pembentuk sikap adalah komponen kognitif atau pengetahuan, dimana komponen tersebut dipengaruhi oleh tingkat pendidikan seseorang. Azwar (2007) menambahkan beberapa faktor yang dapat memengaruhi sikap seseorang dapat meliputi pengalaman individu, pengaruh orang yang dianggap penting, dan kebudayaan.

Berdasarkan tinjauan per subvariabel, diketahui bahwa responden memiliki sikap baik terbanyak pada subvariabel masalah makan dan gizi anak. Sementara itu, responden memiliki sikap kurang baik terbanyak pada subvariabel memilih makanan. Bila dikaitkan dengan pembahasan subvariabel pengetahuan, hal ini tentu berbeda dengan studi terdahulu yang menyebutkan bahwa pengetahuan seseorang memengaruhi sikapnya.

Faktor yang memengaruhi kesenjangan ini salah satunya yaitu kemajuan teknologi informasi. Banyaknya informasi yang ada tidak menjamin semua informasi yang dipaparkan bersifat fakta. Saat ini banyak iklan di televisi, radio, maupun media cetak yang mempromosikan makanan cepat saji/olahan/jajanan merupakan pilihan makanan yang baik untuk anak. Iklan tersebut memberikan pesan sugesti yang dapat memengaruhi opini seseorang dan akhirnya memengaruhi pembentukan sikap (Azwar, 2007).

Kemudian, subvariabel masalah makan dan gizi anak. Peneliti berasumsi walaupun ibu memiliki keterbatasan pengetahuan dalam mengetahui istilah masalah makan dan gizi anak, namun ibu memiliki kemauan dan keinginan untuk mencegah masalah gizi pada anak, sehingga sikapnya pun baik. Hal ini dibuktikan dengan hasil analisis menyatakan semua ibu akan terus memberikan makanan seimbang kepada anak walaupun anaknya sulit makan.

Hasil analisis pada penelitian ini menunjukkan bahwa status gizi anak yang baik dilatarbelakangi oleh sikap ibu dalam pemenuhan gizi anak. Hal ini didukung oleh penelitian Pratama (2012) yang mengemukakan ada pengaruh yang signifikan antara sikap ibu dengan status gizi balita. Ibu yang memiliki sikap kurang baik berkemungkinan memiliki balita dengan status gizi kurang lebih besar daripada ibu yang memiliki sikap baik.

Pada penelitian ini diketahui bahwa mayoritas ibu memiliki perilaku yang baik dalam pemenuhan gizi balita. Hasil penelitian ini sejalan dengan penelitian yang dilakukan oleh Pratama (2012) dan Huriah (2006) yang mengemukakan mayoritas ibu memiliki perilaku yang baik dalam pemenuhan gizi anak.

Menurut teori Precede (Binkley \& Johnson, 2013), faktor yang membentuk perilaku seseorang mencakup faktor predisposisi, faktor pemungkin, dan faktor penguat. Faktor predisposisi yang memengaruhi perilaku ibu yang baik dalam penelitian ini yakni pengetahuan dan sikap. Pengetahuan ibu yang cukup baik mengenai pemenuhan gizi balita merupakan dasar bagi terbentuknya sikap dan akhirnya dapat membentuk perilaku baik (Azwar, 2007).

Faktor pemungkin yang memengaruhi perilaku ibu yang baik dalam penelitian ini yakni ketersediaan dan keterjangkauan pelayanan kesehatan di kelurahan Pancoran Mas seperti posyandu dan puskesmas. Selain itu, penghasilan yang memadai dapat memfasilitasi perilaku ibu dalam memenuhi kebutuhan gizi anak. Dengan penghasilan tersebut, ibu dapat membeli makanan bergizi untuk anaknya (Fitriyani, Sahar, \& Wiarsih, 2011).

Faktor penguat dalam penelitian ini yang turut berperan dalam membentuk perilaku ibu yang baik yakni peran ibu kader, tenaga professional, dan tokoh panutan (RT/RW/Lurah/Camat/Walikota) yang secara sinergis mendukung upaya dalam menangani masalah gizi balita.

Apabila dilihat persubvariabel, responden memiliki perilaku baik tertinggi dalam hal mengolah makanan, sedangkan memiliki perilaku kurang baik tertinggi yakni dalam memilih makanan. Menurut teori, salah satu hal yang memengaruhi perilaku seseorang yakni sikap orang tersebut 
(Notoatmodjo, 2007). Dalam hal memilih makanan, perilaku ibu yang kurang baik ini didasari oleh sikapnya yang juga kurang baik.

Kemudian, peneliti berasumsi sikap ibu yang baik mengenai masalah makan dan gizi turut membentuk perilaku baik dalam hal mengolah makanan. Hal ini dikarenakan salah satu strategi mengatasi masalah makan pada anak adalah dengan mengkreasikan cara pengolahan makanan.

Pada penelitian ini terlihat adanya kecenderungan bahwa semakin baik perilaku ibu dalam pemenuhan gizi anak, maka akan semakin baik pula status gizi anak. Hal ini sesuai dengan penelitian yang dilakukan Jelantik (2012), dimana pada ibu yang memiliki perilaku baik dalam pemenuhan gizi, memiliki anak dengan status gizi baik.

\section{Kesimpulan}

Mayoritas responden memiliki tingkat pengetahuan cukup, sikap cukup baik, serta perilaku yang baik dalam pemenuhan gizi balita. Hasil penelitian ini dapat membantu perawat dalam menyusun strategi yang dibutuhkan untuk meningkatkan pengetahuan, sikap, dan perilaku ibu terkait gizi balita ke tingkat yang lebih baik. Penelitian selanjutnya perlu dilakukan dengan menggunakan teknik pengambilan sampel yang berbeda, melibatkan ibu yang memiliki balita usia 6-59 bulan, serta dapat menggunakan metode observasi untuk mengukur variabel perilaku ibu (MR, AG, INR)

\section{Referensi}

Apooh, Yaa, L., \& Krekling, S. (2005). Maternal nutritional knowledge and child nutritional status in the volta region of Ghana. London: Blackwell Publishing.

Azwar, S. (2007). Sikap manusia: Teori dan pengukurannya. Yogyakarta: Pustaka Pelajar Offset.

Binkley, C. J., \& Johnson, K. W. (2013). Application of the PRECEDE-PROCEED planning model in designing an oral health strategy. Journal of Theory and Practice of Dental Public Health, 1(3), http://www.shar milachatterjee.com/ojs-2.3.8/index.php/JTPDPH/ article/view/89.

Byrd-Bredbenner, C., Abbot, J. M., \& Cussler, E. (2008). Mothers of young children cluster into 4 groups based on psychographic food decision influencers. Nutr Res, 28, 506-516.

Hidayati, R. N. (2011). Hubungan tugas kesehatan keluarga, karakteristik keluarga dan anak dengan status gizi balita di wilayah Puskesmas Pancoran Mas Kota Depok. Tesis Tidak Dipublikasi. Fakultas Ilmu Keperawatan. Universitas Indonesia. Depok.

Huriah, T. (2006). Hubungan perilaku ibu dalam memenuhi kebutuhan gizi dengan status gizi batita di Kecamatan Beji Kota Depok. Tesis Tidak Dipublikasi. Fakultas Ilmu Keperawatan. Universitas Indonesia. Depok.

Ihsan, M., Hiswani., \& Jemadi. (2013). Faktor-faktor yang berhubungan dengan status gizi anak balita di desa teluk rumbia kecamatan singkil kabupaten aceh singkil tahun 2012. Jurnal Gizi, Kesehatan Reproduksi dan Epidemiologi 2(1), 1-10.

Jelantik, I. G. (2012). Perbedaan perilaku pemberian makanan oleh ibu yang memiliki anak balita gizi buruk dengan gizi baik di wilayah kerja puskesmas pringgasela Kabupaten Lombok Timur tahun 2012. Media Bina Ilmiah 6(4), 48-52.

Kementerian Kesehatan Republik Indonesia. (2010). Riset kesehatan dasar: Riskesdas 2010. Diperoleh dari: http://www.riskesdas.litbang.depkes. go.id/download/TabelRiskesdas2010.pdf.

Khomsan, A. (2000). Teknik pengukuran pengetahuan gizi. Bogor: Institut Pertanian Bogor.

Khotimah, N. S., Siregar, R., \& Mardiana. (2012). Hubungan pengetahuan gizi ibu dan pola makan balita dengan status gizi balita (12-59 bulan) di wilayah kerja puskesmas gandus kecamatan gandus-palembang tahun 2010. Jurnal Pembangunan Manusia, 6(2).

Lozoff, B., Jimenez, E., \& Smith, J. B. (2006). Double burden of iron deficiency in infancy 
and low socioeconomic status: a longitudinal analysis of cognitive test scores to age 19 years. Arch Pediatr Adolesc Med, 160(11), 1108-1113.

Notoatmodjo, S. (2007). Promosi kesehatan dan ilmu perilaku. Jakarta: Rineka Cipta.

Potter, P. A., \& Perry, A.G. (2005). Buku ajar fundamental keperawatan: Konsep, proses, dan praktik. Jakarta: Penerbit Buku Kedokteran EGC.

Fitriyani, P., Sahar, J., \& Wiarsih, W. (2011). Pengalaman keluarga memenuhi kebutuhan nutrisi balita gizi kurang. Jurnal Keperawatan Indonesia, 14(3), 150-156.

Profil Kesehatan Kota Depok Tahun 2012. (2013). Diperoleh dari http://dinkes.depok.go.id/wpcontent/uploads/profil-kesehatan-kota-depoktahun-2012.pdf.

Pratama, A. R. (2012). Pengaruh tingkat pendidikan, tingkat pendapatan, pengetahuan ibu, sikap ibu, dan perilaku ibu terhadap status gizi balita di kecamatan kesamben kabupaten jombang. (Skripsi Tidak Dipublikasi). Universitas Negeri Surabaya. Surabaya
Putri, R. N. A. (2008). Faktor-faktor yang berhubungan dengan status gizi baduta berdasarkan imt menurut umur di wilayah kerja Puskesmas Pancoran Mas Depok tahun 2008 (analisis data sekunder). Skripsi. Fakultas Kesehatan Masyarakat. Universitas Indonesia. Depok.

Uripi, V. (2004). Menu sehat untuk balita. Jakarta: Puspa Swara anggota IKAPI.

Vereecken, C., \& Maes, L. (2010). Young children's dietary habits and associations with the mothers nutritional knowledge and attitudes. Appetite, $54,44-51$.

Victora C.G., Adair L., Fall, C., Hallal P.C., Martorell R., Richter L., \& Sachdev, H.S (2008). Maternal and child undernutrition: Consequences for adult health and human capital. Lancet, 371(9609), 340 -357.

Wong, D. L., Hockenberry-Eaton, M., Wilson, D., Winkelstein, M. L., \& Schwartz, P. (2001). Wong's essential of pediatric nursing. Philadelphia: Mosby, Inc. 